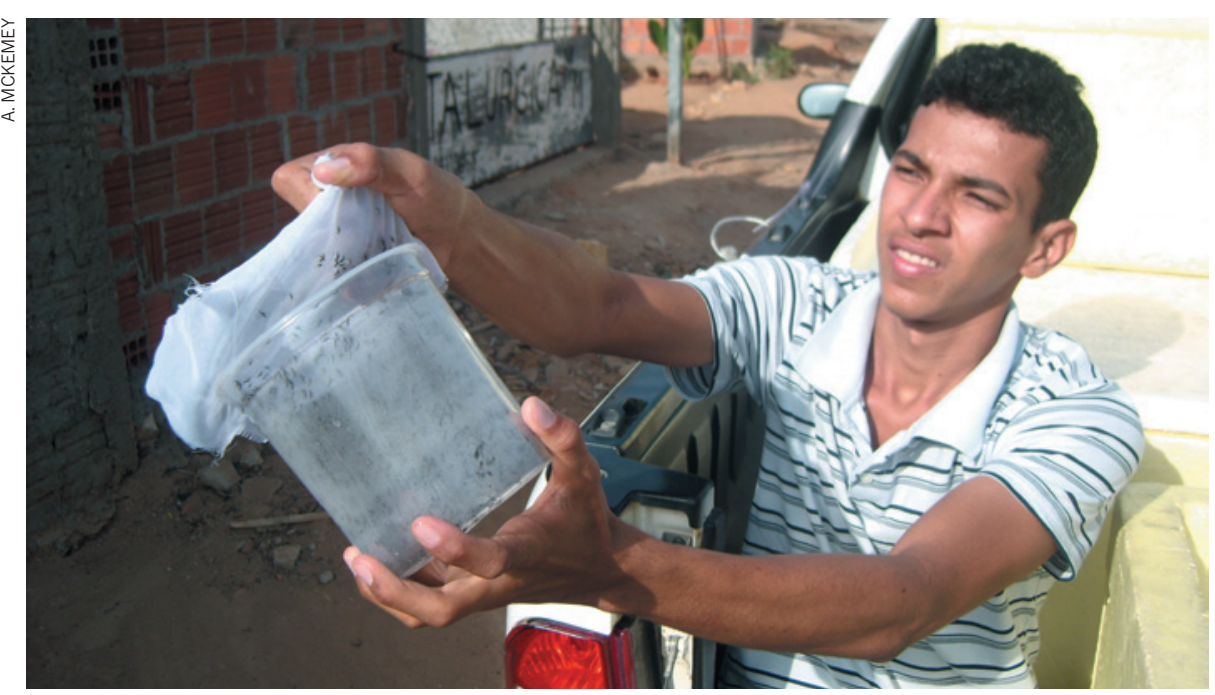

The release of transgenic mosquitoes is welcome news in Brazil, but less so in Key West.

PUBLIC HEALTH

\title{
Florida abuzz over mosquito plan
}

\section{Biotech firm's bid to control dengue fever using genetically modified insects faces growing public opposition.}

\section{BY AMY MAXMEN}

$\mathrm{I}$ t took a decade for the biotechnology firm Oxitec to develop genetically modified mosquitoes whose progeny die before they can spread dengue fever. But it took only three months for Mila de Mier to gather 100,000 names from people opposed to the release of the mosquitoes in Key West, Florida, where the potentially lethal disease is making a comeback.

The US Food and Drug Administration (FDA) is currently reviewing an application from Oxitec, based in Abingdon, UK, and says that the mosquitoes will not be released without federal approval, which is not expected to happen soon. But that has not quelled the public furore, a sign of the communications challenge faced by those hoping to deploy genetically engineered (GE) animals for food or public health. An opaque system for reviewing applications does little to clear up the confusion.

"The more questions we ask, the more confused we are," says de Mier, a Key West business woman, who started the petition in April. "I started thinking, 'Oh my goodness, what if these mosquitoes bite my boys or my dogs? What will they do to the ecosystem?'”.

The Oxitec mosquitoes are an engineered version of Aedes aegypti, the main transmitter of dengue fever. The modified males carry a lethal gene that is kept in check only by a special diet. They survive to mate with wild females, but the offspring die. In field tests conducted in Juazeiro, Brazil, the engineered insects shrank the A. aegypti population in an 11 -hectare area by $85 \%$ over one year.

The online petition de Mier initiated to stop Oxitec has garnered national attention. It alludes to concerns that GE mosquitoes might harm people and that mosquito-eating native Florida species, such as bats, could go hungry. It also raises the prospect of other unintended consequences, such as the emergence of a deadlier dengue virus that gets around the absence of $A$. aegypti. In response, the company says that the virus already evolves in humans to optimize its fitness. It also notes that male mosquitoes do not bite, and that although a few engineered females might be released, any DNA they might transmit is not toxic or allergenic. Entomologists say that no animals in Florida feast solely on this species of mosquito.

Florida's negative reaction contrasts with that in Bahia state, Brazil, where residents in Juazeiro cheered the opening of an Oxitec mosquito-production facility on 7 July. Some Brazilians initially voiced concerns similar to those of de Mier and others, says Margareth Capurro, a biologist at the University of São Paulo, who led the Juazeiro trial. But she and her team engaged the community through meetings, radio and local television before seeking approval for their trial from Brazil's agency for biotechnological safety, CTNBio. Capurro continues to spread the message that GE mosquitoes are not a threat and that they fight a disease that residents know and fear. "We release the mosquitoes around 8 a.m., and the kids like to follow us," she says. "Sometimes you see them running back to older people in the village to explain what we're doing."

Dengue fever is a smaller problem in the United States than in Brazil, but health officials were alarmed when it reappeared in Florida three years ago after an absence of more than 70 years. Since 2009, 94 cases have been reported in Key West, and dengue prevention has become a top priority. Tourists often visit the area after stopping in dengue-infested countries, and a population of $A$. aegypt $i$ is there ready to spread the disease once it arrives, says entomologist Michael Doyle, director of the Florida Keys Mosquito Control District (FKMCD) in Stock Island, a taxpayer-funded operation that spends more than US\$1 million a year to control A. aegypti in Key West with insecticides.

In 2010, the FKMCD asked Oxitec if it would do a field trial with its mosquitoes in Key West. Oxitec responded in its usual way. "We say we're delighted to help, and then we ask about the regulatory system in that country," says Hadyn Parry, the firm's chief executive.

In November 2011, Oxitec applied for approval by the FDA, which regulates GE animals that affect other animals (those that affect plants, such as crop pests, are regulated by the US Department of Agriculture). Although the FDA process is neither clear-cut nor rapid, a media report that month prompted concerns among residents after it suggested that officials were hoping for a mosquito release as early as January 2012. Doyle then organized a public meeting in March that de Mier attended, and which prompted her to start her petition. "I thought that if I presented the facts in a reasonable manner, people would respond in a reasonable way. But that's not happening," Doyle says.

Parry has offered to speak to de Mier about her concerns, but she has declined. Any rapprochement is unlikely to accelerate what is expected to be a long journey through the FDA's regulatory pipeline.

\section{CORRECTION}

The News story 'Palm-oil boom raises conservation concerns' (Nature 487, 14 ; 2012) wrongly attributed $27 \%$ of Indonesia's deforestation to palm-oil planting. This figure was only for the area of Ketapang. It also said that this figure would rise to $40 \%$ by 2020 , but that is the area in Ketapang projected to be given over to oil palm and is not due solely to deforestation. 